\title{
KREATIVITAS KOMBINASI PANGAN BERBAHAN BAKU JAGUNG DAN KELAPA
}

\section{Creativity of Raw Material Combination from Corn and Coconut}

\author{
D.U.M. Susilo ${ }^{1)}$ dan Elsa Sari Yuliana ${ }^{1)}$ \\ ${ }^{1}$ Politeknik Negeri Pontianak, Jurusan Teknologi Pertanian dan Akuntansi, Jalan Jenderal Ahmad \\ Yani Pontianak, Kalimantan Barat 78124
}

\begin{abstract}
Corn and coconut are some of the main local commodities of Pematang Tujuh Village, Rasau Jaya Sub-district, Kubu Raya Regency, West Kalimantan. Both of these plants have the potential to be developed into a variety of processed food products, whether processed separately or combined. Community devotion is done to provide guidance and mentoring to partners who are appointed to develop the local potential that belongs to a new business to help sustain family income, especially partners, as a pioneer in the business in question. A personal approach with informal and formal methods to partners is done gradually for expected applications and acceptance. The result is that the partners are able to process the variety of processed products that are trained with the correct and attractive packaging techniques so that they have the feasibility to be marketed, although in the meantime, the market reached is the nearest market from the production site. The hope of this business into business opportunities that can be developed more widely for the welfare of partners
\end{abstract}

Keywords: local commodities, corn, coconut, new business

\begin{abstract}
ABSTRAK
Jagung dan kelapa merupakan sebagian komoditi lokal unggulan Desa Pematang Tujuh Kecamatan Rasau Jaya Kabupaten Kubu Raya Kalimantan Barat. Kedua tanaman ini berpotensi untuk dikembangkan menjadi ragam produk olahan pangan, baik diolah terpisah maupun dikombinasikan. Pengabdian masyarakat yang dilakukan memberikan pembimbingan dan pendampingan kepada mitra yang ditunjuk untuk mengembangkan potensi lokal yang dimiliki menjadi usaha baru untuk membantu menopang penghasilan keluarga terutama mitra binaan sebagai pioner dalam usaha yang dimaksud. Pendekatan secara personal dengan metoda informal dan formal kepada mitra dilakukan secara bertahap untuk aplikasi dan penerimaan yang diharapkan. Hasil yang diperoleh adalah mitra binaan mampu mengolah ragam olahan produk yang dilatihkan dengan teknik pengemasan yang benar dan menarik sehingga memiliki kelayakan untuk dapat dipasarkan, walaupun sementara ini, pasar yang dijangkau adalah pasar terdekat dari tempat produksi. Harapannya usaha ini menjadi peluang bisnis yang dapat dikembangkan lebih luas demi kesejahteraan mitra
\end{abstract}

Kata Kunci: komoditi lokal, jagung, kelapa, usaha baru

\section{PENDAHULUAN}

Tanaman kelapa dan jagung menjadi tanaman unggulan dan primadona bagi masyarakat desa pematang Tujuh dengan varietas jagung yang ditanam adalah jagung manis, jagung hibrida dan jagung lokal. Sebagian besar produksinya dijual dalam bentuk segar dipasar-pasar tradisional di Kecamtan Rasau Jaya, ataupun dipinggirpinggir jalan didepan rumah mereka masing-masing, ataupun dijual dalam bentuk biji jagung kering/jagung pipilan, diolah menjadi jagung rebus dan jagung bakar (Suarni dan Sarasutha, 2002). 
Sedangkan salah satu limbahnya berupa kolobot jagung belum banyak dimanfaatkan secara optimal. Selama ini hanya dimanfaatkan oleh masyarakat setempat sebagai pupuk. Padahal jagung dapat diolah menjadi selai jagung, permen jelly jagung, biskuit jagung, dan cake jagung (Suryani dkk., 2004).

Sedangkan untuk tanaman kelapa varietas yang paling banyak dibudidayakan adalah kelapa hibrida dan hasil panen mereka selain dijual dalam bentuk segar juga diolah masyarakat menjadi kopra dan pada umumnya dijual pada pedagang pengumpul. Selain produk tesebut kelapa dapat diolah menjadi selai atau sirup kelapa (Fachruddin, 2008), permen kecap air kelapa, dan cake kelapa (Yuliani, 2011: Sukamto, 2001; Palungkun, 1993)).

Sasaran Kegiatan pengabdian pada masyarakat (PKM) ini ditujukan pada kelompok PKK dan kelompok tani jagung dan kelapa di Desa Pematang Tujuh yang telah memiliki 8 kelompok taniyang berasal dari 6 dusun yaitu dusun Suka Damai,dusun Suka Bakti, dusun Rejo Agung, dusun Purwodadi, dusun Kebun Jeruk dan dusun Bina Karya. Semua Kelompok tani ini bergabung dalam GAPOKTAN dengan naman NUR BAKTI diketuai oleh Bapak kadir. Berdasarkan informasi dari ketua Gapoktan bahwa sampai saat Kegiatan Gapoktan masih aktif dan pertemuan rutin sering dilaksanakan pada minggu pertama setiap bulannya di rumah anggota GAPOKTAN secara bergilir. Masingmasing kelompok tani saling bekerjasama dan saling membantu memecahkan masalah yang terjadi berkaitan dengan budidaya tanaman lokal. Kelompok tani yang aktif dalam kegiatan sosial dan penanganan budidaya jagung dan kelapa adalah kelompok tani Suka Maju yang dipimpin oleh bapak Solohin

Kelompok PKK diketuai ibu Yanti yang merupakan istri pak Kades pematang tujuh bernama Surjana. Berdasarkan informasi yang diperoleh dari ibu PKK bahwa anggota PKK saat ini berjumlah 43 orang yang rata-rata istri petani jagung dan kelapa. Olahan komuditi tersebut masih sederhana dijadikan Kopra dan jagung pipilan yang dijemur menggunakan sinar matahari. Keterbatasan olahan pangan kelapa dan jagung dikarenakan selama ini masyarakat desa pematang Tujuh kurang mendapatkan pembimbingan dan pelatihan IPTEK untuk mengolah produk yang lebih variatif dan bernilai ekonomis Kegiatan rutin kelompok PKK setiap bulan diisi dengan arisan, posyandu, olahraga dan pengajian.

\section{BAHAN DAN METODE}

\section{Bahan}

Bahan yang digunakan pada kegiatan pengabdian masyarakat meliputi; jagung, tepung jagung, kelapa muda, kelapa tua, air kelapa muda, air kelapa tua terigu, tepung tapioka, gula pasir, margarine, telur, mentega, susu bubuk, selasih, gula merah, bumbu pelengkap, minyak goring, bubuk kedelai, tempe, keju, coco chips, ceres, masako, cengkeh, baking powder, vanili, bawang merah, bawang putih, cabe, keju dan kayu manis

\section{Alat}

Alat yang digunakan pada kegiatan pengabdian masyarakat meliputi:, mixer, baskom, blender, piring, mangkok, pisau, talenan, pisau, parang, sutil, waja, penyaring, panci kukus, panci rebus, kompor, sendok, garpu, toples, cetakan, cup sealer, botol kecap, cetakan kue kering, spatula, teko ukur, gelas, sealer, timbangan serbet, tabung gas beserta selangnya, obeng, oven, onderpan, plastik,Loyang tipis

\section{Metode}

Metode pelaksanaan kegiatan dilaksanakan dalam dua tahapan, yaitu transfer teknologi dengan pemberian teoritis secara singkat/penyuluhan dan metoda demonstrasi yaitu praktek pembuatan produk .Metoda teoritis merupakan penyampaian seluruh aspek pengerjaan yang akan dilakukan pada semua 
rencana yang dirancang yaitu pembagian kelompok kerja,tahapan olah, sistem pengemasan dan pemasaran,sedangkan tahap demosntrasi dimaksudkan untuk mempraktekkan secara langsung terhadap teori sebelumnya. Tahapan akhir kegiatan seluruh peserta di wajibkan mengisi kuisioner yang disiapkan pelaksana untuk mengetahui efek kegiatan yang dilaksanakan dan seluruh peralatan serta bahan produksi yang telah disediakan oleh tim pelaksana PKM diserahkan kepada mitra kerja sebagai modal awal keberlanjutan kegiatan.

\section{HASIL DAN PEMBAHASAN}

\section{Hasil}

Terdapat tujuh (7) produk hasil olahan pangan pada pelaksanaan kegiatan pengabdian yang terdiri dari selai kelapa jagung, sirup kelapa, permen jelly jagung, kecap air kelapa, biskuit jagung, cake jagung kelapa dan kelapa parut kering. Produk ini kemudian dilakukan penilaian oleh seluruh peserta yang terlibat .Pada akhir kegiatan, dilakukan pengisian kuisioner kepada 25 peserta yang mengikuti kegiatan. Hasil kuisioner dirincikan pada Tabel 1, 2 dan 3.

\section{Pembahasan}

Kegiatan ini memberikan kesempatan kepada seluruh peserta untuk memberikan penilaian terhadap produk yang dihasilkan. Penilaian dilakukan sebelum dan seduah kegiatan dilakukan. Berdasar pada Tabel 1, 2 dan 3 maka masing-masing peserta meberikan penilaian berbeda terhadap apa yang dilihat dan diproduksi oleh mereka.

Tabel 1. Keterampilan peserta mengolah produk sebelum kegiatan

\begin{tabular}{lccccccc}
\hline Produk & $\begin{array}{c}\text { Selai } \\
\text { kelapa } \\
\text { jagung }\end{array}$ & $\begin{array}{c}\text { Sirup } \\
\text { kelapa }\end{array}$ & $\begin{array}{c}\text { Permen } \\
\text { jelly } \\
\text { jagung }\end{array}$ & $\begin{array}{c}\text { Kecap } \\
\text { kelapa }\end{array}$ & $\begin{array}{c}\text { Biscuit } \\
\text { jagung }\end{array}$ & $\begin{array}{c}\text { Cake } \\
\text { jagung } \\
\text { kelapa }\end{array}$ & $\begin{array}{c}\text { Kelapa } \\
\text { parut } \\
\text { kering }\end{array}$ \\
\hline $\begin{array}{l}\text { Peserta } \\
\text { Terampil }\end{array}$ & 2 & 2 & 4 & 0 & 5 & 10 & 1 \\
$\begin{array}{l}\text { Peserta } \\
\text { Tidak } \\
\text { Terampil }\end{array}$ & 23 & 23 & 21 & 25 & 20 & 10 & 24 \\
\hline
\end{tabular}

Tabel 2. Keterampilan peserta mengolah produk kuliner sesudah kegiatan

\begin{tabular}{lccccccc}
\hline Produk & $\begin{array}{c}\text { Selai } \\
\text { kelapa } \\
\text { jagung }\end{array}$ & $\begin{array}{c}\text { Sirup } \\
\text { kelapa }\end{array}$ & $\begin{array}{c}\text { Permen } \\
\text { jelly } \\
\text { jagung }\end{array}$ & $\begin{array}{c}\text { Kecap } \\
\text { kelapa }\end{array}$ & $\begin{array}{c}\text { Biscuit } \\
\text { jagung }\end{array}$ & $\begin{array}{c}\text { Cake } \\
\text { jagung } \\
\text { kelapa }\end{array}$ & $\begin{array}{c}\text { Kelapa } \\
\text { parut } \\
\text { kering }\end{array}$ \\
\hline $\begin{array}{l}\text { Peserta } \\
\text { Terampil }\end{array}$ & 25 & 25 & 25 & 21 & 25 & 25 & 21 \\
$\begin{array}{l}\text { Peserta } \\
\text { Tidak } \\
\text { Terampil }\end{array}$ & 0 & 0 & 0 & 4 & 0 & 0 & 4 \\
\hline
\end{tabular}

Tabel 3. Pendapat peserta tentang produk yang dihasilkan

\begin{tabular}{llllllll}
\hline Produk & $\begin{array}{l}\text { Selai } \\
\text { kelapa }\end{array}$ & $\begin{array}{l}\text { Sirup } \\
\text { kelapa }\end{array}$ & $\begin{array}{l}\text { Permen } \\
\text { jelly }\end{array}$ & $\begin{array}{l}\text { Kecap } \\
\text { kelapa }\end{array}$ & $\begin{array}{l}\text { Biscuit } \\
\text { jagung }\end{array}$ & $\begin{array}{l}\text { Cake } \\
\text { jagung } \\
\text { kagung }\end{array}$ & $\begin{array}{l}\text { Kelapa } \\
\text { parut } \\
\text { kering }\end{array}$ \\
MBE & 21 & 22 & 25 & 25 & 10 & 10 & 23 \\
TMTBE & 5 & 3 & 0 & 0 & 10 & 15 & 2 \\
\hline
\end{tabular}

Keterangan:

MBE adalah menarik dan bernilai ekonomi

TMBE adalah tidak menarik dan tidak bernilai ekonomi 


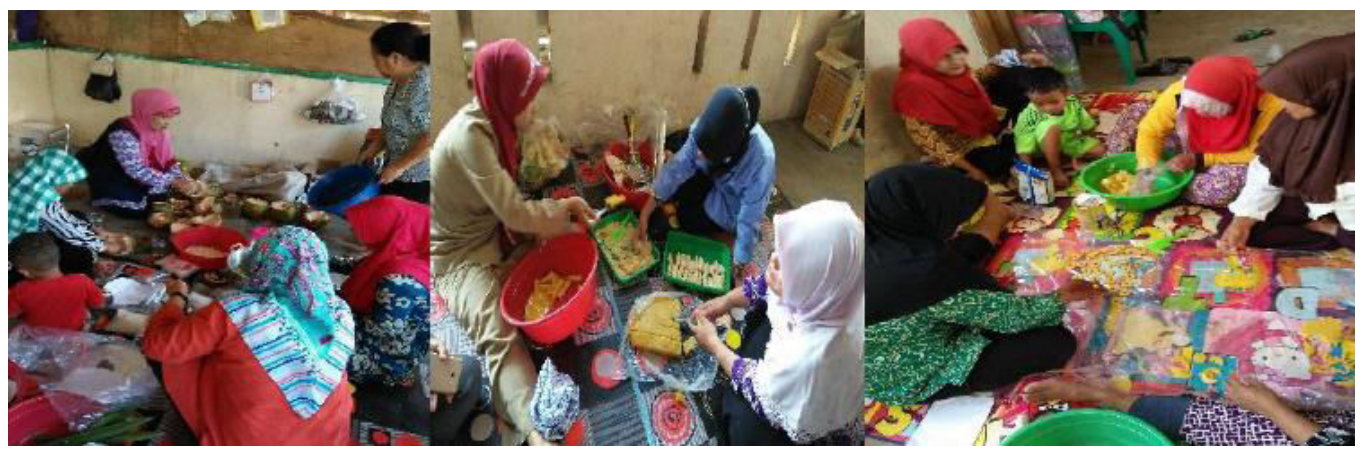

Gambar 1. Aktivitas mitra dalam pembuatan produk olahan jagung dan kelapa

Hasil penilaian sebelum kegiatan dilaksanakan disajikan pada Tabel 1. Data menyimpulkan bahwa $90 \%$ peserta belum memiliki keterampilan dalam berbagai olahan produk yang akan diperkenalkan dan dilatihkan, sehingga sangat diperlukan perhatian lebih dalam implementasi semua sistem olah secara menyeluruh untuk perolehan hasil yang diinginkan. Belum dimilikinya keterampilan disebabkan oleh kurangnya informasi secara lisan dan tulisan yang diperoleh mitra, sehingga tidak terpikirkan dalam memanfaatkan potensi lokal menjadi usaha baru yang sesungguhnya dapat meningkatkan pendapatan keluarga.Beberapa gambar aktivitas mitra mendapatkan pengetahuan dan ketrampilan olahan kelapa dan jagung dibawah ini.

Setelah kegiatan berlangsung, maka memberikan dampak yang sangat berarti bagi mitra dalam hal kemampuan dan keterampilan yaitu dari setiap olahan produk yang dilatihkan terjadi peningkatan jumlah peserta yang memahami dan terampil dalam produksinya. Pada beberapa produk seperti permen jelly jagung dan kecap air kelapa, peserta yang mampu melakukan tata kelola sebesar 100\%, sedangkan pemahaman produk lainnya diatas 95\% (Tabel 2). Hal ini membuktikan bahwa informasi, pelatihan dan pendampingan dapat meningkatkan kemampuan seluruh mitra yang dilatihkan untuk berkreasi dengan pemanfaatan tanaman lokal yang dimiliki.
Penilaian dari sisi ketertarikan dan nilai ekonomis disajikan pada Tabel 3.Secara umum peserta memiliki ketertarikan terhadap produk yang diciptakan dan satu produk yaitu kecap air kelapa memiliki ketertarikan hingga 100\%. Hal ini membuktikan bahwa produk yang dihasilkan menarik dan memiliki nilai jual apalagi di tunjang dengan sistem pengemasan yang menarik, sehingga menambah daya tarik dan nilai jual produk yang dihasilkan, sedangkan produk cake jagung memiliki ketidaktertarikan hingga 60 $\%$. Hal ini disebabkan karena kesalahan dalam prosedur yaitu pengaturan suhu yang tidak tepat sehingga berpengaruh terhadap tampilan dan rasa yang dihasilkan, namun telah di temukan penggunaan suhu yang tepat, sehingga pada saat pengulangan diperoleh hasil yang diinginkan.

\section{KESIMPULAN}

Berdasarkan evaluasi tim pelaksana kegiatan pengabdian kepada masyarakat, maka dapat disimpulkan:

1. Kegiatan pengabdian kepada masyarakat di Desa Pematang Tujuh berlangsung sesuai rencana dengan dukungan kehadiran mitra kerja dan pejabat terkait seperti kepala dusun dan kepala desa setempat.

2. Peserta mengalami penambahan pengetahuan dan keterampilan dalam olahan produk pangan berbahan jagung dan kelapa. 
3. Peserta memiliki kemampuan dan keterampilan dalam mengoperasionalkan seluruh peralatan produksi.

\section{DAFTAR PUSTAKA}

Fachruddin L. (2008). Membuat Aneka Selai. Kanisius. Yogyakarta.

Palungkun, R. (1993). Aneka Produk Olahan Kelapa. Penebar Swadaya. Jakarta.

Suarni dan Sarasutha, I.G.P. (2002). Teknologi pengolahan jagung untuk meningkatkan nilai tambah dalam pengembangan agroindustri. Prosiding
Seminar Nasional, BPTP Sulawesi Tengah

Sukamto. (2001). Upaya Meningkatkan Produksi Kelapa. Penebar Swadaya. Jakarta.

Suryani, A., Hambali, E., dan Rivai, M. (2004). Membuat Aneka Selai. Penebar Swadaya. Jakarta.

Yuliani, H.R. (2011). Karakterisasi selai tempurung kelapa muda. Prosiding Seminar Nasional Teknik Kimia “Kejuangan”. Yogyakarta. 